\title{
Fosfonet Sodium Anhydrous
}

National Cancer Institute

\section{Source}

National Cancer Institute. Fosfonet Sodium Anhydrous. NCI Thesaurus. Code C83722.

An anhydrous sodium salt formulation of phosphonoacetic acid with activity ag ainst herpes simplex viruses and other members of the herpes virus family. Fosfonet inhibits viral DNA polymerase and inhibits the synthesis of viral DNA. 